\title{
Effects of dose and period of sewage sludge application on soil, tree and pasture components in a Pinus radiata D. Don silvopastoral system
}

\author{
A. Rigueiro-Rodríguez $\cdot$ S. Castro $\cdot$ \\ M. R. Mosquera-Losada
}

Received: 26 April 2009/Accepted: 28 January 2010/Published online: 17 February 2010

(C) Springer Science+Business Media B.V. 2010

\begin{abstract}
The adequate use of sewage sludge in silvopastoral systems could enhance positive relationships between pasture and trees to increase farm incomes at medium, short and long term. The main aspects related to adequate sewage sludge use as a fertiliser are dose and timing of application, once heavy metal concentrations have been taken into account. This paper aims to evaluate the date and dose of sewage sludge applications on soil $(\mathrm{KCl} \mathrm{pH}$, soil organic matter), pasture production and tree growth after the establishment of a silvopastoral system with Pinus radiata D. Don developed on sandy soils with an initial $\mathrm{pH}$ of 5 . It is concluded that the contribution of sewage sludge does not modify the soil conditions in a consistent manner, but cause detectable edaphic improvements depending on the climatic conditions, the results of which are manifested in enhancement of pasture and trees. The application of high doses of sewage sludge is the best option within those studied, as tree growth and pasture production tend to be increased. There are no clear effects with regard to the date of application, but if the desire is to increase pasture production during the spring season, the sewage sludge will be applied in the first of the application dates, whereas
\end{abstract}

A. Rigueiro-Rodríguez $\cdot$ S. Castro ·

M. R. Mosquera-Losada ( $\square$ )

Crop Production Department, Escuela Politécnica

Superior, Campus de Lugo, 27002 Lugo, Spain

e-mail: mrosa.mosquera.losada@usc.es the greatest growth in the diameter of trees is produced in the plots fertilised in February, although the date of application does not appear to have a clear effect on their growth in height.

Keywords $\mathrm{pH} \cdot$ Climatic factors .

Fertiliser - Waste

\section{Introduction}

Afforestation practices on former agricultural land have been very important in the last decade throughout Europe, as one million hectares have been afforested between 1994 and 1999 (ECC 2004) due to European agro-environment policies (Regulation no. 2080/92). In Galicia (NW Spain), it has accounted for 400,000 hectares in a region of three million hectares (Xunta de Galicia 2001). Galicia is one of the most fire-prone areas of Europe, accounting for about $16 \%$ of the whole area of Europe affected by forest fires (Rigueiro-Rodríguez et al. 2005). Traditional afforestation practices in this region transform agricultural land into forestland without understory management, which increases shrubland biomass under the trees and generates fire risk due to the excellent climatic conditions for understory growth during the spring, which may burn in the subsequent dry summer (Rigueiro-Rodríguez et al. 2008).

Silvopastoral systems have been described as a sustainable method of land use (UN 1992) that are 
promoted by European directives (Council Regulation on Support for Rural Development and Agricultural Fund for Rural Development, 15 September 2005) and could reduce fire risk (Rigueiro-Rodríguez et al. 2008). At the same time, they would generate early income from forestland (Fernández-Núñez et al. 2008) through the use of understory as a resource to feed animals and thereby produce animal products, such as meat, milk, wool, etc. Silvopastoral system management should aim to enhance pasture and tree component production through a better implementation of management practices, such as fertilization. European waste management is aimed at the recycling of residues by using them as a fertiliser in agriculture. This would allow nitrogen, phosphorous and potassium use by crops providing that contaminants, such as heavy metals ( $\mathrm{Zn}$, $\mathrm{Cu}, \mathrm{Cr}, \mathrm{Hg}, \mathrm{Cd}, \mathrm{Pb}$ and $\mathrm{Ni}$ ), are below predetermined thresholds (European Directive 91/271/EEC). The optimum use of sewage sludge should be based on the nitrogen sludge component, as this is the nutrient that is most highly concentrated and most needed by crops, once the heavy metals are below the regulated limits. Nitrogen dose inputs should be calculated based on crop needs as traditionally do the main sludge management factories in the area. Soil nitrogen content is not usually taken into account due to the complex nitrogen cycling which causes either volatilisation or leaching of this element in the area due to the usually adequate temperatures and precipitation. EPA (1994) does not consider soil available nitrogen to estimate sewage sludge applications. Soil nitrogen from successive sludge applications is usually storaged as part of the soil organic matter and it is not available to plants in the area from one year to another (RigueiroRodríguez et al. 2000; Whitehead 1995). If an organic fertiliser instead of mineral nitrogen is added, then the mineralization rate should be taken into account as explains EPA (1994), which is site specific and should be tested in a particular area.

Recent studies have been conducted in Pinus radiata, the most popular species for afforestation in the Province of Lugo (Rigueiro-Rodríguez et al. 2005), based on the dose of sewage sludge on lands with an initial water $\mathrm{pH}$ of 7 and 4.5. These studies revealed positive (Mosquera-Losada et al. 2006) and negative effects of sewage sludge use on tree growth (López-Díaz et al. 2007). These results were due to the different effects caused on grass production and, therefore, the different competitive relationship established between tree and pasture. Apart from the dose, the period of application of the nitrogen fertiliser plays an important role in the use of this nutrient, which can easily be leached or volatilized if it is not used immediately by the pasture once applied due to low temperatures or lack of water (MosqueraLosada and González-Rodríguez 1999b; Peyraud et al. 2004). The period of application is very important because, if the sewage sludge is applied early in winter, nutrients can be leached as the pasture is not able to absorb them because of the low temperatures that limit pasture growth. However, if applied too late, nutrient use is delayed and the growing season could be shortened, increasing the use of concentrates to feed the animals, as enough pasture is not available. The best period is difficult to identify if organic fertilizers such as sewage sludge are used, as uptake and mineralization processes are involved. These increase the time required to make the nitrogen available when compared with inorganic fertilizers, which have already mineralised nitrogen forms like nitrate and ammonium.

This paper aims to evaluate the period and the dose of sewage sludge application on the soil $(\mathrm{KCl} \mathrm{pH}$, soil organic matter (SOM)), pasture production and tree growth after the establishment of a silvopastoral system with Pinus radiata D. Don developed on sandy soil.

\section{Materials and methods}

The experiment was established in the Spring 2001, in Lugo (NW Spain $43^{\circ} 14^{\prime} \mathrm{N}, 7^{\circ} 21^{\prime} \mathrm{W}, 450 \mathrm{~m}$ above sea level). This area is within the Atlantic biogeographic region and it is characterised by an average annual rainfall of $1,086 \mathrm{~mm}$ and an average annual temperature of $11.5^{\circ} \mathrm{C}$. This zone has mild temperatures and abundant rainfall in the period of major pasture growth (springtime), and a summer with frequent periods of drought. These drought periods are not favourable for tree growth and seriously limit the production of pasture. This compels the use of stored forage to feed the livestock during shortage period. The soil in the area of the experiment was an abandoned agricultural soil with a sandy texture, and a high percentage of organic matter $(8 \%)$ and total nitrogen $(0.3 \%)$.

Before establishing the experiment, the soil was deep-ploughed and rotated. The experimental area 
was divided into 30 plots of $150 \mathrm{~m}^{2}$ delimited by plantation lines. In each plot, 25 one year old trees $(5 \times 5)$ of Pinus radiata D. Don were planted in March of 2001, at a density of 1,667 trees per hectare (frame of $3 \times 2 \mathrm{~m}$ ). In October 2001 the area was hand sown with a mixture of $12.5 \mathrm{~kg} \mathrm{ha}^{-1}$ Lolium perenne variety Brigantia, $12.5 \mathrm{~kg} \mathrm{ha}^{-1}$ Dactylis glomerata variety Ártabro and $4 \mathrm{~kg} \mathrm{ha}^{-1}$ of Trifolium repens cv Huia.

At the end of 2001, 10 treatments were applied, arranged following a randomised block design with three replicates. Treatment 1 was an unfertilized control (NF). Sewage sludge with $200 \mathrm{~kg}$ total nitrogen $\mathrm{ha}^{-1}$ year $^{-1}$ were applied to the soil on four different application dates: (2) December (F1), (3) January (F2), (4) February (F3) and (5) March (F4). These treatments were designated "DB". Sewage sludge with $400 \mathrm{~kg}$ total nitrogen $\mathrm{ha}^{-1}$ year $^{-1}$ were applied to the soil on the same four application dates: (6) December (F1), (7) January (F2), (8) February (F3) and (9) March (F4). These treatments were designated "DA". Sewage sludge treatments were not supplemented with synthetic nitrogen. Applied doses of nitrogen as sewage sludge were based on previous experiments carried out in the area and in the recommendations described by the USA Environment Protection Agency (EPA 1994). Traditional mineral nitrogen doses in Galicia based on pasture nitrogen requirements are usually between 80 and $120 \mathrm{~kg} \mathrm{~N} \mathrm{ha}^{-1}$ and year $^{-1}$ for grazing and silage pasture production, respectively. If the same doses has to be added to soil with the sewage sludge and following the nitrogen mineralization rate of $20 \%$ described for anaerobic sewage sludges by EPA (1994) around 320 and $480 \mathrm{~kg}$ total $\mathrm{N} \mathrm{ha}^{-1}$ year $^{-1}$ to provide 64 and $128 \mathrm{~kg}$ available $\mathrm{N} \mathrm{ha}^{-1}$ and year ${ }^{-1}$, should be added to the soil. Doses over $400 \mathrm{~kg}$ total
$\mathrm{N}$ ha $^{-1}$ year $^{-1}$ at the establishment has demonstrate to reduce tree growth in the area, due to the enhancement of the tree-pasture competition (López-Díaz et al. 2007). For this reason, doses of 200 and 400 total nitrogen per hectare and year were tested to provide an annual rate of 40 and $80 \mathrm{~kg}$ available $\mathrm{N}^{-1}$ and year ${ }^{-1}$. Low nitrogen doses were used to test the benefits that this low doses could provide in extensive systems that usually receives less nitrogen inputs in order to reduce farm production costs. In addition there was a treatment 10 with mineral fertiliser (MIN), consisting of application each year of $500 \mathrm{~kg} \mathrm{ha}^{-1}$ year $^{-1}$ of a compound mineral fertiliser 8:24:16 $\left(\mathrm{N}: \mathrm{P}_{2} \mathrm{O}_{5}: \mathrm{K}_{2} \mathrm{O}\right)$ in March. The applications of sewage sludge and inorganic fertiliser were repeated during 2002, 2003 and 2004. The fertilisation with sludge in the first application of the second year (December 2002 (F1)) could not be carried out due to technical problems (loading).

The sewage sludge was from the Lugo Sewage Farm operated by GESTAGUA S.A., which processes the municipal wastes of Lugo by anaerobic digestion. The average composition of the sewage sludge applied each year is summarised in Table 1. In this table it can be seen that its levels of heavy metals are far below the maximum limits indicated in the Spanish legislation (R.D. 1310/1990) for agricultural use.

In order to evaluate the effect of the treatments on soil, a composite sample of four random samples were taken from each experimental unit in December of 2003 and 2004, using a core $(10 \mathrm{~cm})$ at a depth of $25 \mathrm{~cm}$. This is the depth indicated in the Spanish legislation for evaluating the use of sewage sludge in agriculture (R.D. 1310/1990). The samplings were taken just before the application of sludge in December. Later, in the laboratory, the samples were

Table 1 The composition of sewage sludge used in this experiment and maximum values of the concentration of heavy metals in sewage sludge for $\mathrm{pH}$ and $\mathrm{pH}<7$, according to $\mathrm{RD} 1310 / 90$

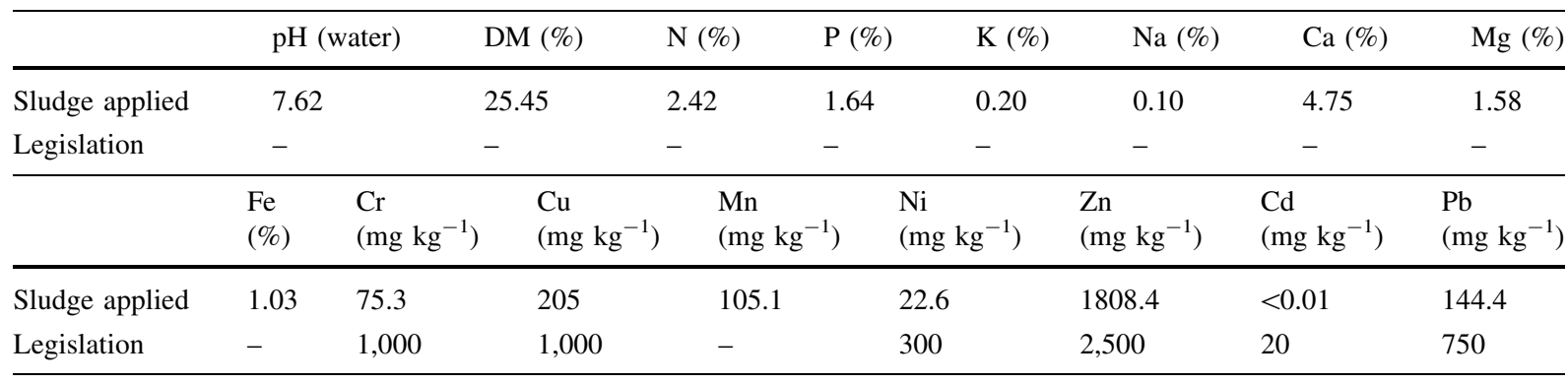


allowed to air-dry and sieved ( $2 \mathrm{~mm}$ mesh). After which, the $\mathrm{KCl} \mathrm{pH}$ was determined $\mathrm{KCl} 0.1 \mathrm{M}(1: 15)$ using the Guitián and Carballás (1976) methodology. Soil organic matter (SOM) was analysed with Saverlandt method (Guitián and Carballás 1976).

In the trees, the height was measured using a pole and the basal diameter was measured using a calliper. These two variables were measured for the 9 inner trees of each experimental unit in order to avoid the "border effect". The measurements were made at the end of April 2001, February 2002 and in February and October 2004.

Pasture production was estimated by collecting four random samples from each plot (between the central trees), using a $0.30 \times 0.30$ surface square and hand shears. These samples were transported to the laboratory and weighed while fresh. Afterwards, $100 \mathrm{~g}$ were separated from each sample and oven-dried to determine their dry weight $\left(60^{\circ} \mathrm{C} \times 48 \mathrm{~h}\right)$ and dry matter production. The dates of the sampling in 2002 and 2003 were June and November, coinciding with summer and autumn. In the third year (2004), three harvests of grass were made (May, July and November) coinciding with spring, summer and autumn. Once the plots had been sampled, the grass was mowed and removed from all the experimental units.

The results obtained were analyzed using ANOVA (randomised block design) using the LSD Test with the Statistical Packet SAS (2001). The model used for soil variables was: $\mathrm{SOILijkl}=\mu+\mathrm{Si}+\mathrm{Bj}+\mathrm{Dk}+$ $\mathrm{Yl}+(\mathrm{SD}) \mathrm{ik}+(\mathrm{SB}) \mathrm{ij}+(\mathrm{SY}) \mathrm{il}+(\mathrm{DY}) \mathrm{kl}+(\mathrm{BY}) \mathrm{jl}$ $+(B D) j k+(S D Y) i k l+(Y B D) l h k+(S B D) i j k$
+ cijkl and the model for tree and pasture variables was: $\mathrm{Pijk}=\mu+\mathrm{Si}+\mathrm{Bj}+\mathrm{Dk}+(\mathrm{SB}) \mathrm{ij}+(\mathrm{SD}) \mathrm{ik}+$ (BD)jk + eijk. SOILijkl: Soil variables Pijk: the dependent variable; Pijk:pasture production and tree variables with Pijk: the dependent variable; $\mu$ : the variable mean; Si: i sludge dose fertilization effect; $\mathrm{Bj}$ : j block effect; Dk: $\mathrm{k}$ date of fertilization effect and their double interactions; and sijk is the error component. LSD test was used for subsequent pairwise comparisons $(P<0.05 ; a=0.05)$ if the ANOVA was significant.

\section{Results}

Climate

The relationship between the average temperature and rainfall of the last 30 years indicates a hydric deficit in June, July and August in the zone (Fig. 1). However, during this study, this deficit was only found in July and August in 2002, August and September in 2003 and July in 2004. August of 2004 was much wetter than usual. February through July 2004 were much drier than usual, but not limited pasture or tree growth as temperature (2T) line in the ombrothermic diagram was below precipitation (PP) line (Fig. 1). Temperature was below $6^{\circ} \mathrm{C}$ only in January $2003\left(5.4^{\circ} \mathrm{C}\right)$ and December $2004\left(5.3^{\circ} \mathrm{C}\right)$. These temperatures were sufficiently low to limit vegetation growth (Carballeira et al. 1983).

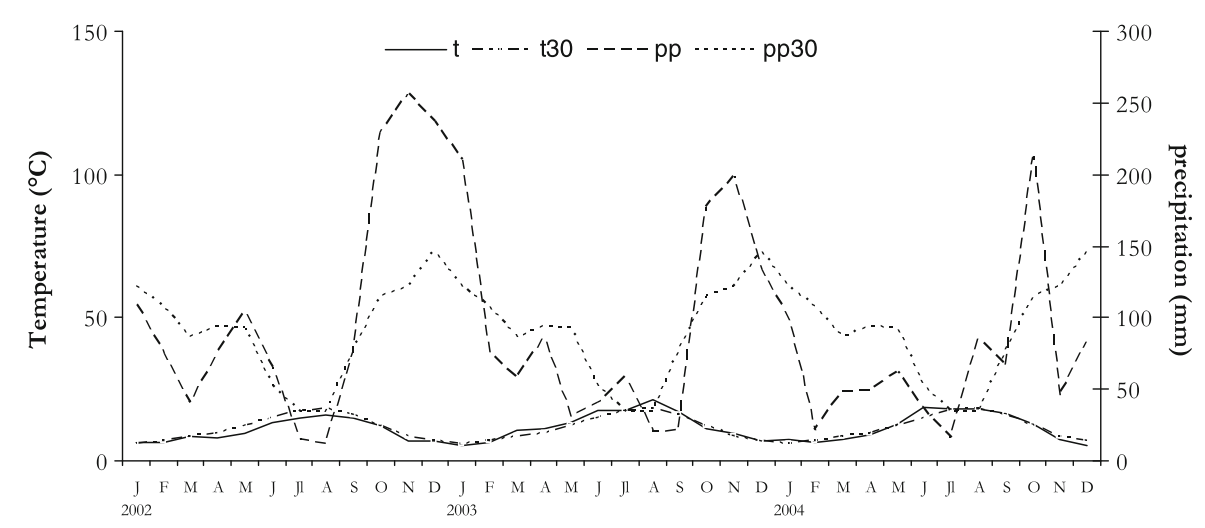

Fig. 1 Ombrothermic diagram corresponding to the years of the study and the last 30 years. t30: average 30-year temperatures (1974-2004); t: average temperatures of the year studied; pp30: average 30-year rainfall (1974-2004); $\mathrm{p}$ : average rainfall of the year studied 
Soil

The ANOVA showed a significant interaction of year $\times$ dose $\times$ date for $\mathrm{KCl} \mathrm{pH}(P<0.001)$. At the end of 2004 (Fig. 2), the applications of high doses of sewage sludge in January 2003 or February 2003 caused an increase in soil $\mathrm{KCl} \mathrm{pH}$ with respect to the low doses applied in February or March, the nofertilisation treatment and the treatment with high doses applied in the first date (remember that due to the extremely wet ground it was not possible to apply sewage sludge on this date in the year previous to the sampling of December 2004). However, $\mathrm{KCl} \mathrm{pH}$ was not affected by treatments in 2003 .

The application of the treatments resulted in a clear trend in the soil organic matter in the last year of the study $(P<0.07$ in the interaction year $\times$ dosage $\times$ date). The soil organic matter varied between 7.51 and $10.05 \%$ for the first sampling, and between 2.48 and $7.02 \%$ for the second sampling (Fig. 3). The

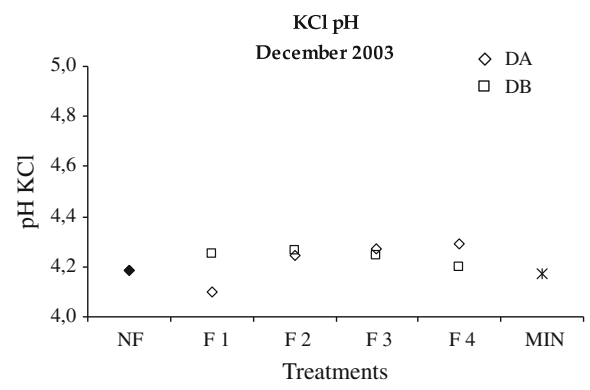

Fig. 2 Soil $\mathrm{KCl} \mathrm{pH}$ in each samplings and treatments applied, where NF: no fertilisation; F1: fertilisation in December; F2: fertilisation in January; F3: fertilisation in February; F4: fertilisation in March; MIN: fertilisation each year with percentage of soil organic matter decreased from 2003 to 2004, which can be explained by the better climatic conditions that occurred in 2004 that allowed for the improved incorporation of the tree and grass roots into the soil and for the mineralisation of the sewage sludge. In 2004, the last application of low doses of sewage sludge (F4) generally caused an increase in the soil organic matter compared with the other treatments.

Tree growth

Doses and date of application had variable effects on tree height and tree diameter (Figs. 4, 5). Tree height was significantly modified by the doses applied in February $(P<0.001)$ and October $2004(P<0.1)$. Diameter showed just one significant response in February $2004(P<0.05)$, also modified by the dose applied. The annual average tree growth was greatest in the fourth year. This was the only year without

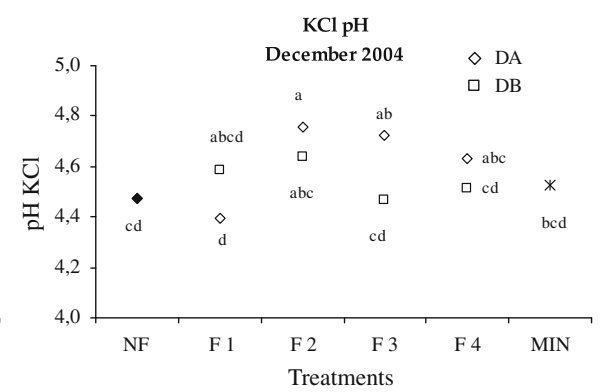

$500 \mathrm{~kg} \mathrm{ha}^{-1}$ de 8:24:16 together with $\mathrm{N}$ in March; DB: $200 \mathrm{~kg} \mathrm{~N} \mathrm{ha}^{-1}$; DA: $400 \mathrm{~kg} \mathrm{~N} \mathrm{ha}^{-1}$. Different types of letters indicate significantly different averages between treatments for each sampling

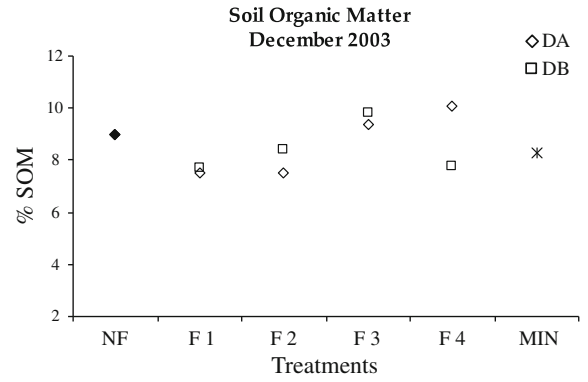

Fig. 3 Percentage of organic matter for each of the samplings performed and the different treatments applied, where NF: no fertilisation; F1: fertilisation in December; F2: fertilisation in January; F3: fertilisation in February; F4: fertilisation in

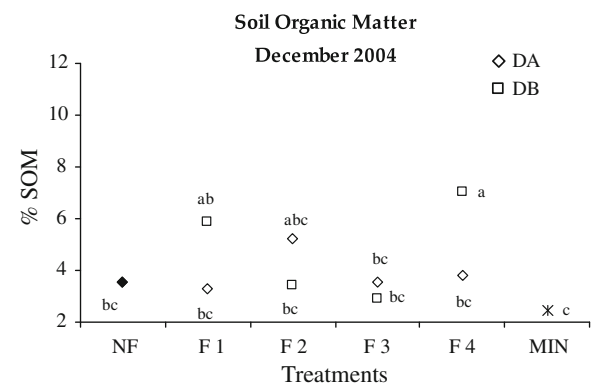

March; MIN: fertilisation each year with $500 \mathrm{~kg} \mathrm{ha}^{-1}$ de 8:24:16 together with $\mathrm{N}$ in March.; DB: $200 \mathrm{~kg} \mathrm{~N} \mathrm{ha}^{-1}$; DA: $400 \mathrm{~kg} \mathrm{~N} \mathrm{ha}^{-1}$. Different types of letters indicate significantly different averages between treatments for each sampling 

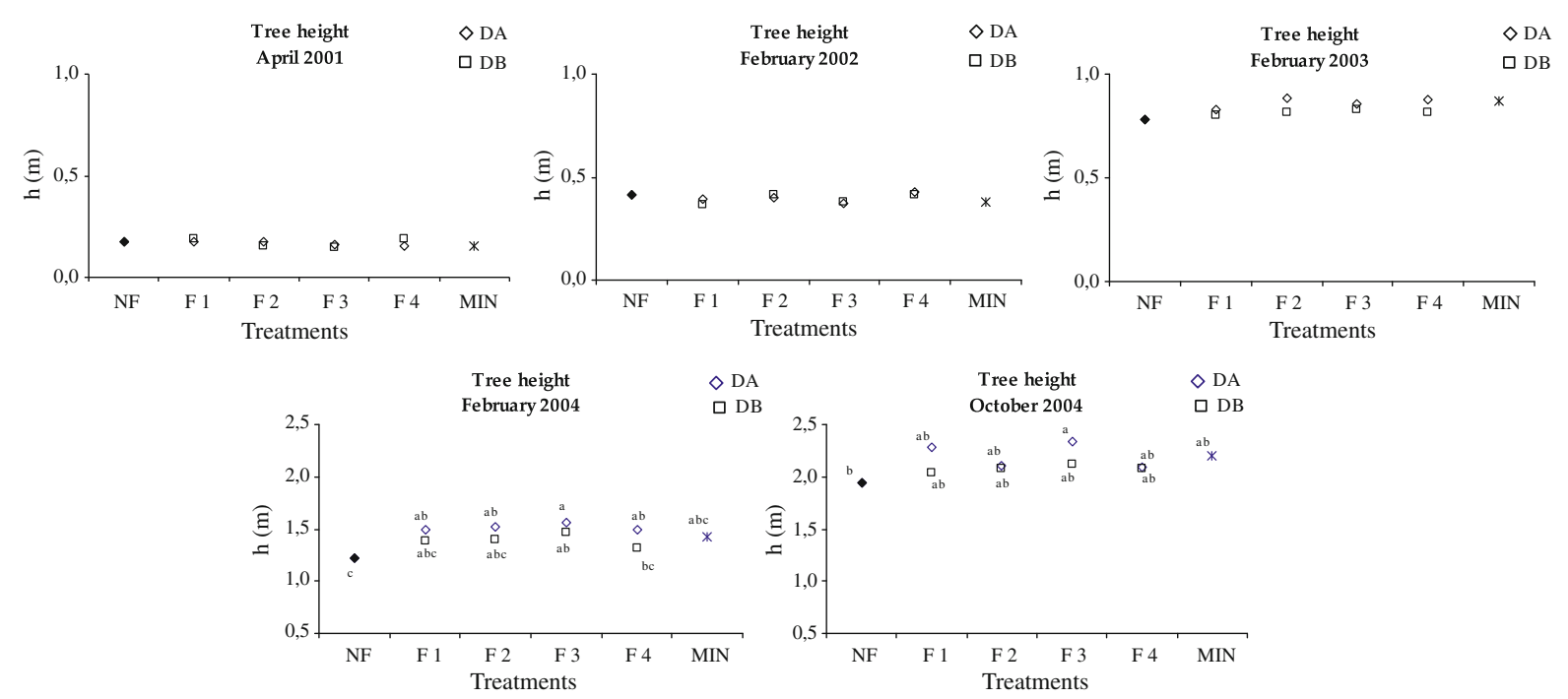

Fig. 4 Values of tree height in metres for each of the measurements performed and the different treatments applied, where NF: no fertilisation; F1: fertilisation in December; F2: fertilisation in January; F3: fertilisation in February; F4: fertilisation in March; MIN: fertilisation each year with
$500 \mathrm{~kg} \mathrm{ha}^{-1}$ de 8:24:16 together with $\mathrm{N}$ in March.; DB:200 kg N ha ${ }^{-1}$; DA: $400 \mathrm{~kg} \mathrm{~N} \mathrm{ha}^{-1}$. $(\mathrm{h}=$ total tree height) Different types of letters indicate significantly different averages between treatments for each sampling
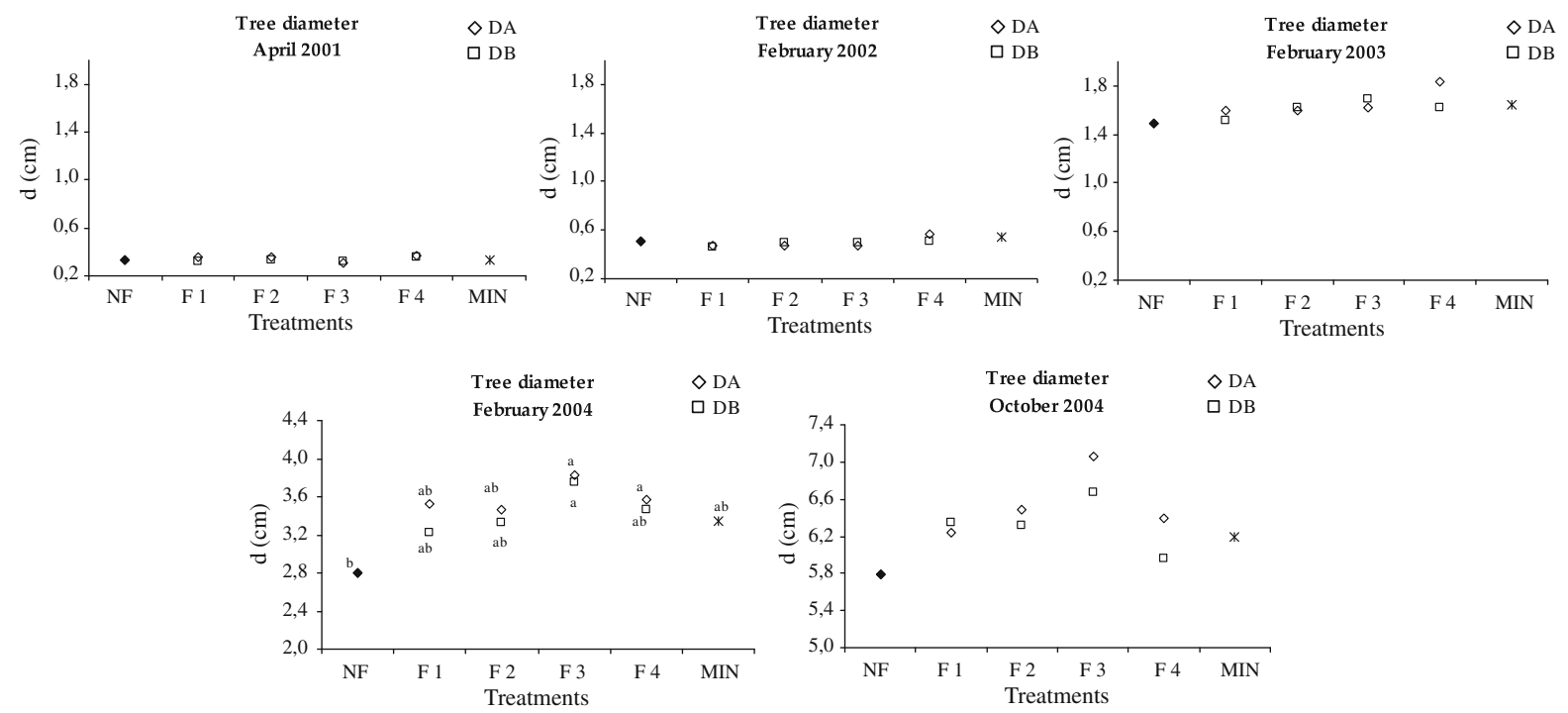

Fig. 5 Diameter values of the trees in centimetres for each of the measurements performed and for the different treatments applied, where NF: no fertilisation; F1: fertilisation in December; F2: fertilisation in January; F3: fertilisation in February; F4: fertilisation in March; MIN: fertilisation each

year with $500 \mathrm{~kg} \mathrm{ha}^{-1}$ de 8:24:16 together with $\mathrm{N}$ in March; DB:200 kg N ha ${ }^{-1}$; DA:400 kg N ha ${ }^{-1}$. $(d=$ diameter at the trees base) Different types of letters indicate significantly different averages between treatments for each sampling

drought during the summer, as the $2 \mathrm{~T}$ line was below PP line (precipitation) in the Fig. 1. Tree height at the end of the experiment varied from 1.95 to $2.34 \mathrm{~m}$ and the base diameter at the end of the experiment had

values of between 5.79 and $7.06 \mathrm{~cm}$, with nearly the same increases independent of which treatment was applied. All the treatments that received high doses of organic fertiliser, independent of the application date, 
increased tree growth in height and diameter in February of 2004, compared to the no-fertiliser treatment. However, most of these differences disappeared in the following sampling at the end of 2004. The exception was the treatment with high doses of sewage sludge applied in the third date. In that treatment, tree height was significantly higher than those not fertilised (NF). The mineral fertiliser treatment and the treatments with low doses of sewage sludge did not differ significantly from the no-fertiliser treatments.

Pasture production

The annual pasture production (Fig. 6) was significantly affected by the doses of sewage sludge applied in the 3 years of the study, although by the application date, only in the first year (Table 2). Analysing the annual production of the sward, the lower production of spring and autumn of the first year was notable compared to the second year and this second year when compared to the third year. This can be explained by the low temperatures until June 2002. That month was the first time that year that the average monthly temperature exceeded $10^{\circ} \mathrm{C}$. This could be the reason that, in this year, the most productive treatment was that of low doses of sewage sludge, compared to the other 2 years in which treatment with high doses of sewage sludge achieved

Table 2 Result of the analysis by ANOVA for the soil $\mathrm{pH}$, height and diameter of trees and grass production in all of the samplings and measurements carried out

\begin{tabular}{lllll}
\hline & $\begin{array}{l}\text { Date of } \\
\text { sampling }\end{array}$ & Dosage & Date & $\begin{array}{l}\text { Dose } \times \\
\text { Date }\end{array}$ \\
\hline Pasture production & 2002 & $* * *$ & $* * *$ & $\mathrm{~ns}$ \\
& 2003 & $*$ & $\mathrm{~ns}$ & $\mathrm{~ns}$ \\
& 2004 & $* * *$ & $\mathrm{~ns}$ & $\mathrm{~ns}$ \\
& Jun-2002 & $* * *$ & $* * *$ & $14 \%$ \\
Dic-2002 & $\mathrm{ns}$ & $\mathrm{ns}$ & $\mathrm{ns}$ \\
Jun-2003 & $\mathrm{ns}$ & $\mathrm{ns}$ & $\mathrm{ns}$ \\
Nov-2003 & $*$ & $\mathrm{~ns}$ & $*$ \\
Prim-2004 & $* * *$ & $*$ & $\mathrm{~ns}$ \\
May-2004 & $* * *$ & $* * *$ & $5 \%$ \\
Jul-2004 & $* * *$ & $\mathrm{~ns}$ & $*$ \\
Nov-2004 & $* *$ & $*$ & $*$ \\
\hline
\end{tabular}

ns not significant; $* P<0.05, * * P<0.01$, *** $P<0.001$ the best pasture growth. The dates that produced the greatest annual productions of grass in 2003 were January and February (F2 and F3). The effect of the contribution of sewage sludge was independent of the application date in the final year of the study (Figs. 6, 7).

Seasonally, as a function of the harvests, an important intra-annual variation was registered, with a progressive decrease of pasture production as each year advanced. This was due to the unfavourable climatic conditions for growing grass at the end of the year. When three harvests per year were carried out, as in 2004, the second harvest tends to be less productive, as there was generally an important drought effect in summer. However, the lack of drought during August 2004 and, together with the adequate temperatures at the beginning of summer, caused a notable increase in the annual production of pasture. The production in autumn of 2004 was also unusually high, as there was practically no summer drought, which together with adequate temperatures favoured pasture production over a longer period of time and was reflected in the autumn harvest.

Analysing each of the harvests (Fig.7), there was a significant effect of the doses and dates of application in June 2002, but not in June 2003. This was contrary to what happened in autumn when production was significantly affected by the interaction doses $\times$ sewage sludge date in the autumn of 2003, but not in 2002. In the significant harvests of the first 2 years, a greater production was found in the second date for low doses of sewage sludge in 2002 and for high doses in 2003. In 2004, all the harvests were significantly affected by the treatments used, in the first harvest by the doses and date independently, and in the second and that of autumn, by the interaction of these two factors. In the first sampling, high doses of sewage sludge produced significantly more pasture than low doses. These in turn were usually more productive than the no-fertiliser or inorganic fertiliser. The exception was for low doses of sewage sludge applied on the last date. Pasture production was greated when fertilised with high doses of sewage sludge on the first date. The same tendency was observed in the second harvest, with late application of sewage sludge significantly increasing pasture production. If the two cuttings are combined, obtaining the spring cutting, it can be seen that no significant differences existed in the global result of 

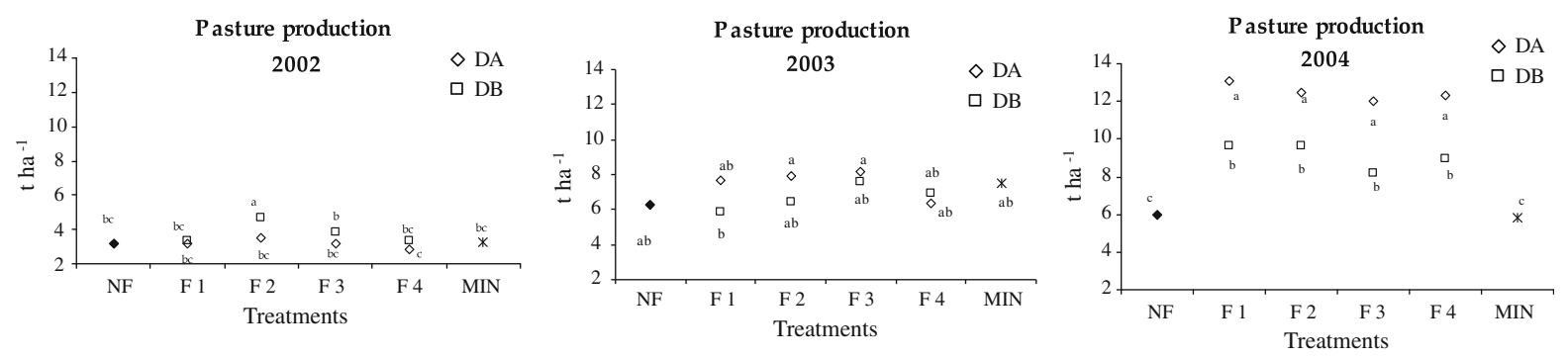

Fig. 6 Production of annual grass in the 3 years studied: 2002, 2003 and 2004, expressed in $\mathrm{tha}^{-1}$, for each of the treatments applied where NF: no fertilisation; F1: fertilisation in December; F2: fertilisation in January; F3: fertilisation in February; F4: fertilisation in March; MIN: fertilisation each

this period between treatments that apply the same doses of sewage sludge. Thus there were no differences among dates of application. In the overall result of the spring production of this last year, pasture production was greatest when high doses of sewage sludge were applied. However, the low doses had higher production than the no-fertiliser and mineral treatments. In the harvest at the end of 2004, the positive effect of high doses of sewage sludge are maintained. This was also detected when low doses of sewage sludge were applied on the second and fourth dates, when compared to the no-fertiliser and mineral treatments, or with the treatments with low doses of sewage sludge on the first and third dates.

\section{Discussion}

When sewage sludge was applied to the soil in high doses in January and February, the result was a significant increased the $\mathrm{KCl} \mathrm{pH}$ and the reduced potential acidity after two consecutive years, as was described by López-Díaz et al. (2007) for soils with a lower $\mathrm{pH}$ (4). This effect could be explained by the action of the cations that were introduced during the sewage application, such as calcium and magnesium (Mosquera-Losada et al. 2010). The lack of response from the $\mathrm{KCl} \mathrm{pH}$ to the high sewage sludge doses that were applied in December could be explained by technical problems that did not allow for the proper application of this treatment; as a result, the cation inputs into the soil were restricted. The high sewage sludge dose inputs in March also did not cause an increase in the soil $\mathrm{KCl} \mathrm{pH}$. The higher temperatures year with $500 \mathrm{~kg} \mathrm{ha}^{-1}$ de 8:24:16 together with $\mathrm{N}$ in March; DB:200 kg N ha ${ }^{-1}$; DA:400 $\mathrm{kg} \mathrm{N} \mathrm{ha}^{-1}$. Different types of letters indicate significantly different averages between treatments for each sampling

during this application period might have enhanced sludge cation leaching instead of cation adsorption into the soil (Nillsson 2003).

In 2003, no clear relationship was established between an increase in the soil organic matter and the application of the different sludge doses or the date of application for the sewage sludge. This lack of a relationship could be explained by the reduced incorporation of the sludge in 2003 and by the fact that the types of soils present at the site are rich in organic matter. However, in 2004, the soil organic matter increased with the low dose of the sewage sludge that was applied on the last date. There was a better incorporation of the sludge into the soil and a better mineralisation rate of the waste during this application as compared to the previous applications.

The application of organic fertilisers improved the development of the woodland in this study. Tree growth was greater in the plots that were fertilised with high doses of sewage sludge in February (F3) in the final year of the study (2004). However, the reduced rate of sewage sludge incorporation into the soil limited the growth response of the trees to the different treatments in the early years of the study. Sewage sludge increased the tree height and the tree diameter, with the greatest increases occurring at the higher doses. These results could be explained by the slow liberation of the nutritional elements by the sewage sludge as compared to the faster liberation exhibited by mineral fertilisers. This slow release facilitates nutrient usage by trees when the pasture development is limited by summer drought (Rigueiro-Rodríguez et al. 2008). The pasture was not able to uptake the nutrients that the trees could absorb 

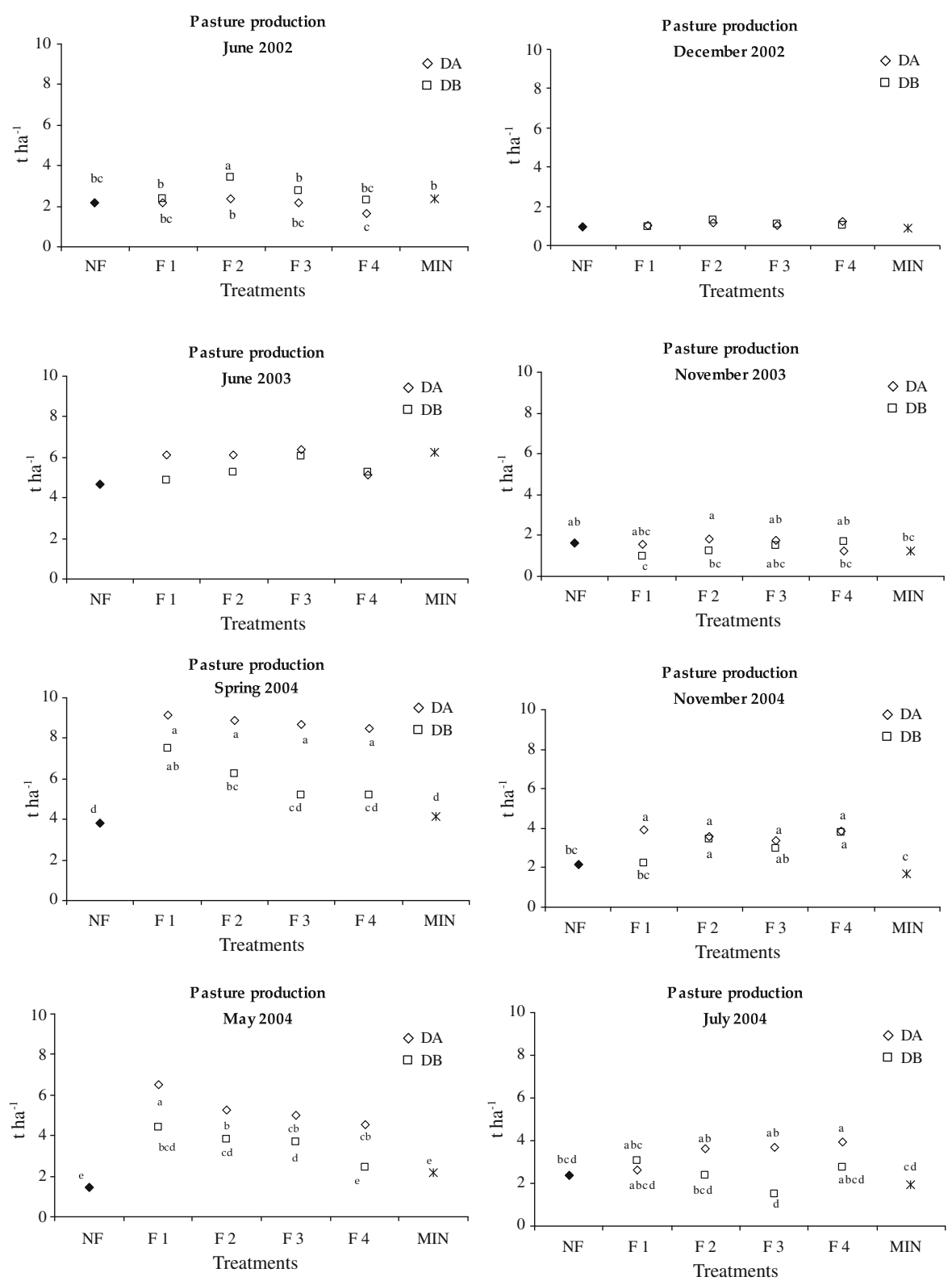

Fig. 7 Pasture production in June and December 2002, June and November 2003 and spring (sum of the production of May and July) and November 2004 expressed in $\mathrm{tha}^{-1}$, for each of the treatments applied where NF: no fertilisation; F1: fertilisation in December; F2: fertilisation in January; F3:

because of the deeper root structure at the current stage of development. In Galicia, the summer drought is one of the main factors limiting tree growth when the temperatures are optimum for the development of forest species (Mosquera-Losada et al. 2006). The

fertilisation in February; F4: fertilisation in March; MIN: fertilisation each year with $500 \mathrm{~kg} \mathrm{ha}^{-1}$ de 8:24:16 together with $\mathrm{N}$ in March.; DB: $200 \mathrm{~kg} \mathrm{~N} \mathrm{ha}^{-1}$; DA: $200 \mathrm{~kg} \mathrm{~N} \mathrm{ha}^{-1}$. Different types of letters indicate significantly different averages between treatments for each sampling

higher growth rates in February 2004 could be explained by the greater availability of water. There was no positive effect on the height of the trees when the inorganic fertiliser was used in comparison to the no-fertiliser treatments, and this result is probably 
due to $\mathrm{N}$ leaching from the mineral treatment. However, a positive response from the tree growth to the inorganic nitrogen fertiliser was exhibited in a more acidic soil (López-Díaz et al. 2007) due to the low pasture production that resulted in low treepasture competition. This result is contrary to the findings of other authors, such as Mosquera-Losada et al. (2006), who reached the conclusion that inorganic fertilisers significantly reduced the growth of Pinus radiata and increased the growth of the pasture in soils with an initial $\mathrm{pH}$ close to neutral, due to the enhancement of the tree-pasture competition Mosquera-Losada et al. (2006).

The annual production of the pasture had a strong dependency on the dose that was applied. No clear differences between the treatments were detected with the different application dates; significantly higher values were seen with the low doses in the first year and with higher doses in the last 2 years. It can be asserted that the pasture production increased from the second year of application when the dose of the sewage sludge was increased, providing that the climatic conditions allow for nutrient uptake by the soil.

In other studies carried out in Galicia with similar fertilisers, it was observed that the average production of the pastures on abandoned agricultural soils was between 6 and $12 \mathrm{Mg} \mathrm{DM}^{-1}$ (MosqueraLosada et al. 1999). In this study, these intervals were reached in the second year and were exceeded in the third year, when they reached 13.08 $\mathrm{Mg} \mathrm{DM} \mathrm{ha}^{-1}$. Generally, the production of grass depends on the meteorological conditions of the growing year, and it is primarily impacted by the variability of rainfall in the summer (Mosquera and González 1999). Observing the inter-annual variation in this study, it can be seen that the highest production was obtained in 2004. Production in 2004 was much higher than in the two previous years because the lack of drought in the summer increased the length of the growing season. Moreover, the application of sewage sludge in this type of experiment usually doubled the pasture production compared with the control when the climatic conditions were good enough to enhance the incorporation and the mineralisation of the sludge (Mosquera-Losada et al. 1999; Smith 1996), as was seen in 2004.

It can be concluded that the contribution of sewage sludge did not significantly modify the soil conditions, although it did cause edaphic improvements that were detectable depending on the climatic conditions and were manifested in improvements in the pasture and in the trees. The application of high doses of sewage sludge is the best option among those that were studied here. The applications significantly increased the tree growth and the pasture production. With regard to the application date, clear effects were not found. However, if an increase in pasture production during the spring season is desired, the sewage sludge should be applied between the end of December and the beginning of January. On the other hand, the maximum growth in the tree diameter was produced in the plots fertilised in February, although there was no clear effect with regard to the growth in tree height.

\section{References}

Carballeira A, Devesa C, Returerto R, Santillán E, Ucieda F (1983) Bioclimatología de Galicia. Fundación Pedro Barrié de la Maza, Santiago de Compostela, Spain

ECC (2004) In support of the communications from the commission to the council and the European parliament on the implementation of the EU forestry strategy. Draft commission staff working document, $83 \mathrm{pp}$

EPA (1994) Land application of sewage sludge. A guide for land appliers on the requirements of the federal standards for the use of disposal of sewage sludge, 40 CFR Part 503. Environment Protection Agency, Washington DC, USA. http://www.epa.gov/npdes/pubs/sludge.pdf (accessed 15 December 2009)

Fernández-Núñez E, Rigueiro-Rodríguez A, Mosquera-Losada MR (2008) Evaluation económique des systèmes sylvopastoraux. In: Rigueiro-Rodríguez A, FernándezLorenzo JL, Mosquera-Losada MR Sysèmes agroforestiers comme technique pour la gestion durable du territorie pp 273-286

Guitián F, Carballás T (1976) Técnica de análisis de suelos. Pico Sacro, Santiago de Compostela, Spain

López-Díaz ML, Mosquera-Losada MR, Rigueiro-Rodríguez A (2007) Lime, sewage sludge and mineral fertilization in a silvopastoral system developed in very acid soils. Agrofor Syst 70:91-101

Mosquera-Losada MR, González-Rodríguez (1999a) Pasture production in northern Spain dairy system. N Z J Agric Res 42:125-132

Mosquera-Losada MR, González-Rodríguez (1999b) Use of first nitrogen in South Europe temperate grassland. 10th nitrogen Workshops, pp 232-233

Mosquera-Losada MR, González-Rodríguez A, RigueiroRodríguez A (1999) Ecología y Manejo de praderas. Ministerio de Agricultura, Tórculo ediciones, Santiago de Compostela, Spain 
Mosquera-Losada MR, Fernández-Núñez E, Rigueiro-Rodríguez A (2006) Pasture, tree and soil evolution in silvopastoral systems of Atlantic Europe. For Ecol Manag 232:135-145

Mosquera-Losada MR, Muñoz-Ferreiro N, Rigueiro-Rodriguez A (2010) Agronomic characterisation of different types of sewage sludge: policy implications. Waste Manage 30(3):492-503

Nillsson SI (2003) Soil acidification. In: Benbi DK, Nieder R (eds) Handbook of processes and modelling in the soilplant system, food products press. Haworth Press, London, pp 177-199

Peyraud JL, Mosquera-Losada MR, Delaby L (2004) Challenges and Tools to develop efficient Dairy Systems based on grazing: how to meet animal performance and grazing Management. Grassl Sci Eur 9:373-384

Rigueiro-Rodríguez MR, Mosquera-Losada MR, GaticaTrabanini (2000) Pasture production and tree growth in a young pine plantation fertilized with inorganic fertilizers and milk sewage in northwestern Spain. Agrofor Syst 48(3):245-254

Rigueiro-Rodríguez A, Mosquera-Losada MR, Romero-Franco R, González-Fernández MP, Villarino-Urtiaga JJ (2005)
Silvopastoral systems as a forest fire prevention technique. In: Mosquera-Losada MR, McAdam J, RigueiroRodríguez A (eds) Silvopastoralism and sustainable land management. CAB International, Wallingford

Rigueiro-Rodríguez A, Fernández-Núñez E, González-Hernández P, McAdam JH, Mosquera-Losada MR (2008) Agroforestry systems in Europe: productive, ecological and social perspectives. In: Rigueiro-Rodríguez A, McAdam JH, Mosquera-Losada MR (eds) Agroforestry in Europe current status and future prospects. Springer, Berlin, pp 43-65

SAS (2001) SAS/stat user's guide: statistics. SAS Institute Inc., Cary, NC, USA

Smith SR (1996) Agricultural recycling of sewage sludge and the environment. CAB International, London, p 382

UN (1992) Agenda 21. United Nations conference on environment and development, United Nations, Rio de Janeiro Whitehead DC (1995) Grassland nitrogen. CAB International, Wallingford, p 416

Xunta de Galicia (2001) O Monte Galego en cifras. Xunta de Galicia http://mediorural.xunta.es/forestal/mtcifras/mtcifras.php 